\title{
ZIMBABWE, TEN YEARS OF INDEPENDENT DEVELOPMENT. A GENERAL OVERVIEW
}

\author{
Martine VANDERMEULEN \\ Belgium - Zimbabwe Friendship Association \\ Boerenlegerstraat 33 \\ 2650 Edegem
}

\section{INTRODUCTION}

It will be obvious from my face that I feel very proud to welcome you at this seminar. I am pleased to see that we are so many to be interested in Zimbabwe, but I also feel embarrassed.

Ten minutes to portray ten years of independent development of a country, one minute for each year, seems a bit unfair towards that country and its people. Especially, if we want to take into account the fact that it is located in the troubled region of Southern Africa and of the high expectations that both the local and international community might have had after more than ten years of liberation struggle.

You will understand that the scope of my presentation can only be limited and general, and I hope that you will accept my apologies for these important issues which I will not be able to mention during this short presentation. 


\section{INDEPENDENCE}

18 April 1980: Rhodesia becomes Zimbabwe. Massive crowds dance to Bob Marley's liberation song " Brother you are right, you have to fight for your right...". The Rhodesian flag comes down and a proud Zimbabwe bird surrounded by four different colours, each symbolizing a major feature of the new country is being raised.

A revolution has taken place, a nation is born, 15 years of struggle and resistance come to and end. Expectations are sky high.

Robert Mugabe - elected as prime minister by a large majority - is given the difficult task of transforming a state ruled by apartheid and capitalist forces into a black majority-ruled nation based on socialist principles.

23 April 1990 in Harare: the celebrations of 10 years of independence have taken place. We can now look back to what has become of this revolution and these promises.

Mugabe's inheritance doesn't seem to be too unpleasant. He acquired a country that due to the war had developed a reasonable infrastructure. The level of production had to be maintained in order to realize the priorities of the new government.

Political stability was the number one issue on the agenda. Reconcilitation between whites and blacks and between the two large ethnic groups, Shona and Ndebele, was endorsed by a coalition government led by Mr. Mugabe (ZANU) and Mr. Nkomo (ZAPU) in which two whites took senior positions. No bloodshed or repression occurred in Zimbabwe until 1982, when the political climate changed drastically. During the integration of the two liberation armies, a number of ZAPU militants left the army. On top of this, large quantities of weapons were found on one of the farms belonging to Mr. Nkomo.

Repression began. Mr. Nkomo had to leave the country and went in exile in London. Violence and terror reigned in Matabeleland. The usual explanation about tribal conflicts between Shona and Ndebele seems to me an easy way out. But it is true that tribal feelings were manipulated into political realities. The underlying cause of this conflict was the drought. The effects of two years continuing drougth were more felt in Matabeleland than in Mashonaland.

In addition, it seems that the freedom fighters from ZANU had received better possibilities to take up responsibilities and obtain high posts in the new government. 
The role of South Africa with its policy of destabilization should not be ignored. That it has played an important role in arming and financing the dissidents in Matabeleland is of common knowledge.

For Mugabe, the solution to the above problems lies in the establishment of a one-party state. For Europeans this form of government seems to be opposed to the principles of democracy, but in the African context of nation building and multi-ethnic societies, it can be seen from a different perspective.

In modifying the structure of the state, Mugabe has always respected the Lancaster House Agreement. This was the condition to obtain independence and was meant to give important political and economic protection to the white minority. It set out that institutional reform can only take place seven years after independence and through a unanumous vote in Parliament. So in 1987 the 30 parliamentary seats (20 in the House of Assembly and 10 in the Senate) reserved for whites were abolished. After the elections they were all taken by ZANU candidates. It is a sign of mutual trust between white and black communities that 15 of these were given to white politicians.

At the end of 1988 the unity talks resulted in the unification of ZANU and ZAPU in one party, ZANU(PF), chaired by R. Mugabe and with Mr. Muzenda and Mr. Nkomo as Vice-Chairmen. The hitherto tense situation eased. The dissident problem in Matabeleland disappeared and there were also some improvements in the economy. The new party already has two million members.

Another major change in the political constitution took place at the end of 1988 . The powers of the presidency were enlarged and a kind of "super-cabinet" was installed with R. Mugabe as President and Mr. Muzenda and Mr. Nkomo as Vice-Presidents.

On 19 December 1989 the first congress of the united party ZANU-PF began. The key question te be addressed is which policy this party wishes to follow. In his opening address R. Mugabe pleaded for a one-party state based on marxist-leninist principles. But this socialism should also take into account the historical, cultural and social values of Zimbabwe. A Zimbabwean socialism, so to speak. And here we are facing an ambiguous situation. Mugabe is sometimes considered to be the only marxist-leninist within his party. That other members adhere to different principles was revealed by the Willowgate corruption scandal. Two cabinet ministers and a governor lost their job, another minister committed suicide. This scandal has convinced a number of Zimbabweans that their leaders opt for a socialist model in order to hide their own greed. Opposition also comes from the trade unions and the student movement. 
A new party, the Zimbabwe Unity Movement, ZUM, was formed by Mr. Edgar Tekere, a former ZANU-PF member. This party openly denounces the corruption and opts for a multi-party democracy and free-market economy.

At the elections in March, ZANU-PF won 116 seats of the 120 parliamentary seats. Mr. Mugabe obtained $78 \%$ of the presidential votes. He called it a "resounding victory" that has given his party the mandate to create a one-party state. But only 54 $\%$ of the country's 4.8 million eligible voters casted their votes, considerably less than the $95 \%$ turn out at the previous elections. This seems to be a sign that an important part of the population is protesting by not voting. Some say that the issue of a one-party state will be decided by a referendum on a later date.

On the economic side the same pragmatic policy can be seen. Whereas most African countries are dependent on a single economic activity, Zimbabwe is not. The country possesses diverse agricultural and mining sectors, while a large part of the industry supplies for the local consumption.

The agricultural sector remains economically the most important area. $70 \%$ of the active population - to a large part women - work in this sector.

Given my "10 years in 10 minutes" constraints, I will not go into this subject, but leave it to Mr. Moyo who will present his views on the Zimbabwean agriculture in the context of the political economy of Zimbabwe. Mr. Stoneman will address the issue of the industrialisation of Zimbabwe in the framework of the SADCC.

Suffice it so say that although there is a generally optimistic attitude on the part of the international donors regarding the economic potential of Zimbabwe, it remains a developing country. The main choice Zimbabwe faces, is between two different political and economic options: promoting industry and commercial farming, as against the economic and social development of the black population. Managers and white farmers would like to consolidate their position and are opposed to major reforms. The majority of the population however is becoming impatient and feels that reforms are not as drastic as they should be. In trying to combine these two poles, pragmatic solutions have to be chosen that usually do not satisfy many people. Major reforms have not yet taken place.

The population has mostly benefitted from the social programmes. Education accounts for $13 \%$ of the annual government budget; it is the second most important sector in terms of government expenditure, after defence. Since independence, schools have been built in every corner of the country. Each child is entitled to free primary education. There are now 2.2 million pupils compared with only 300,000 
ten years ago. It is an enormous success that has also created a great problem. Since the industry is not able to keep the same rhythm of expansion, there are each year about 100,000 youngsters who cannot find a job and who do not want to return to the rural lifestyle. At this moment the curriculum is being reconsidered and the development of vocational training is being looked into.

Free education as well as free health are rights which were won during the liberation struggle.

Zimbabwe can be proud of a health system that has been called one of the best of Africa. Health centers are within walking distance for each citizen; hospitals are well staffed and equipped; there is no shortage of drugs. Child mortality has dropped from $120 / 1000$ to $60 / 1000$ in less than five years.

But maybe it is the area of human relationships that Zimbabwe has been most successful. Rhodesia was built on apartheid and racism; in present-day Zimbabwe an atmosphere of mutual respect and trust is being created. Those whites who have remained and those who have returned after having left, feel at home in this country and are very happy that they can keep their factories or farms. If the black population moans they address themselves this time to their leaders and not to a different colour group.

Is Zimbabwe a revolution that lost its way?

One can answer this question both positively and negatively.

All the plans drawn up during the liberation struggle have not yet been realized. The number of families that have been resettled remains small. True socialism was not created, the migrant labor situation has not changed, creating disrupted families; blacks and whites live quietly next to each other and not with each other...

But on the other hand Zimbabwe is slowly but surely creating its own revolution. The most important message seems to be for its neighbours, Namibia and South Africa, that black majority rule brings about peace between the ethnic and racial groups.

When celebrating ten years of independence in Zimbabwe the crowds no longer dance to Bob Marley's rhythms, but jive to Thomas Mapfumo's Corruption Song.

This is Zimbabwe's own way. 